\title{
Respuesta morfo-productiva de plantas de pimiento morrón biofertilizadas con Pseudomonas putida y dosis reducida de fertilizantes sintéticos en invernadero Morpho-productive response of bell pepper plants biofertilized with Pseudomonas putida and reduced dosage of synthetic fertilizers in greenhouse
}

\author{
Luis Guillermo Hernández-Montiel ${ }^{1}$ (D), Bernardo Murillo-Amador ${ }^{1}$ (D), \\ César Josué Chiquito-Contreras ${ }^{2}$, , Cristina Elizabeth Zuñiga-Castañeda ${ }^{2}$ (1),



\footnotetext{
${ }^{1}$ Centro de Investigaciones Biológicas del Noroeste S.C. Av. Instituto Politécnico Nacional No. 195, Col. Playa Palo de Santa Rita Sur. 23096 La Paz, Baja California Sur, México.

${ }^{2}$ Facultad de Ciencias Agrícolas-Xalapa, Universidad Veracruzana. Circuito Universitario Gonzalo Aguirre Beltrán, Colonia Zona Universitaria. 91090 Xalapa, Veracruz, México.

*Autor para correspondencia / \$Corresponding author (rchiquito@uv.mx)
}

\section{RESUMEN}

La población mundial genera un alto consumo de alimentos, situación que provoca el incremento del uso de fertilizantes sintéticos, los cuales, son costosos y contaminan al medio ambiente. Las bacterias rizosféricas son una alternativa a la aplicación de fertilizantes sintéticos, debido a que estimulan el crecimiento y la productividad de las plantas, no contaminan al medio ambiente y su aplicación es de bajo costo. El objetivo de este estudio fue determinar el efecto de la inoculación de tres cepas rizobacterianas de Pseudomonas putida y aplicación de dos concentraciones de fertilización sintética sobre parámetros morfológicos y rendimiento de fruto en plantas de pimiento morrón variedad 'California Wonder' en condiciones de invernadero. Las plantas fueron inoculadas con tres rizobacterias de $P$. putida catalogadas como FA-8, FA-56 y FA-60 de manera individual y combinada. La concentración de la fertilización sintética fue del 100 y 75\%. Se determinó la altura, el diámetro de tallo, longitud y volumen de raíz, biomasa fresca y seca, rendimiento y contenido de solidos solubles totales de fruto y población bacteriana. Los resultados indican que las bacterias y las dosis de fertilización sintética incrementaron todos los parámetros morfológicos y de productividad

Cita recomendada / Recommended citation:

Hernández-Montiel, L. G., B. Murillo-Amador, C. J. Chiquito-Contreras, C. E. Zuñiga-Castañeda, J. Ruiz-Ramírez y R. Gregorio Chiquito-Contreras. 2020. Respuesta morfo-productiva de plantas de pimiento morrón biofertilizadas con Pseudomonas putida y dosis reducida de fertilizantes sintéticos en invernadero. Terra Latioamericana Número Especial 38-3: 583-596.

DOI: https://doi.org/10.28940/terra.v38i3.651

\section{SUMMARY}

Human populations generate high food consumption, so this situation causes an increase in the application of synthetic fertilizers that are expensive and contaminate the environment. Rhizosphere bacteria are an alternative to synthetic fertilizer application because they stimulate plant growth and productivity, do not contaminate the environment, and their application is low cost. Thus the objective of this study was to determine the inoculation effect of three rhizobacterial strains of Pseudomonas putida and the application of two synthetic fertilization concentrations on the morphological parameters and fruit yield in bell pepper plants variety 'California Wonder' in greenhouse conditions. The plants were inoculated with the rhizobacteria $P$. putida cataloged as FA-8, FA-56, and FA-60, individually and in combination; two concentrations of synthetic fertilization were applied at 100 and $75 \%$ to determine plant height, stem diameter, root length and volume, fresh and dry biomass, yield and total soluble solid content of fruit and bacterial population. The results indicated that bacteria and synthetic fertilization dosage increased all the morphological parameters and productivity of bell pepper. The use of $P$. putida as a bio-fertilizer can be

Recibido / Received: octubre / October 09, 2019. Aceptado / Accepted: enero / January 06, 2020. Publicado en / Published in Terra Latinoamericana 38: 583-596. 
del pimiento morrón. El uso de $P$. putida como un bio-fertilizante puede ser importante dentro de la producción sustentable de cultivos hortícolas como el pimiento morrón.

Palabras clave: Capsicum annuum, rizobacterias, fertilización inorgánica, crecimiento, fruto.

\section{INTRODUCCIÓN}

En México el pimiento morrón (Capsicum annuum L.) también llamado chile verde morrón, por su volumen de producción es considerado un cultivo de importancia económica en el rubro de la exportación agrícola, se estima que más del $80 \%$ de los frutos producidos en suelo mexicano son destinados principalmente hacia los Estados Unidos y Canadá, con valor económico superior a los 520 millones de pesos (SIAP, 2017). Actualmente en el sector hortícola se implementan estrategias de producción intensiva, con la finalidad de aumentar la superficie de cultivo y productividad de las plantas, lo que impulsa el uso constante y excesivo de fertilizantes sintéticos, insumos agrícolas costosos y en extremo contaminantes tanto del suelo y agua, así como de la salud humana y animal (Schulz y Glaser, 2012; Watanabe et al., 2015).

Ante la utilización desmedida de insumos nutricionales sintéticos se han diseñado alternativas de producción agrícola sostenibles e inocuas para los recursos naturales, entre estas se encuentra el aprovechamiento de biofertilizantes elaborados a base de diversos tipos de microorganismos benéficos, como por ejemplo los formulados con cepas rizobacterianas capaces de promover el crecimiento y desarrollo de las plantas (Noh-Medina et al., 2014; HernándezMontiel et al., 2017; Naili et al., 2018), entre las comunidades rizobacterianas destacan numerosas especies distribuidas entre los géneros: Azotobacter, Pseudomonas, Bacillus, Enterobacter, Rhizobium, Azospirillum, entre otros de importancia agrícola (Kamou et al., 2015; Espinosa et al., 2017; PérezVelasco et al., 2019).

Las rizobacterias como agentes biofertilizantes son capaces de estimular directa e indirectamente el crecimiento, desarrollo y productividad de las plantas, mediante diferentes rutas metabólicas como la solubilización del fósforo mineral, fijación biológica del nitrógeno presente en la atmósfera (Zaidi et al., 2015; Coy et al., 2019) y la producción de hormonas important in the sustainable production of horticultural crops such as $C$. annuum.

Index words: Capsicum annuum, rhizobacteria, inorganic fertilization, growth, fruit.

\section{INTRODUCTION}

In Mexico bell pepper (Capsicum annuum L.), also known as green pepper, is considered an important economic crop in agricultural exports because of its production volume; more than $80 \%$ of the fruit produced in Mexican soil is exported mainly to the United States and Canada with an economic value higher than MX 520 million pesos (SIAP, 2017). Currently, in the horticultural sector intensive production strategies have been implemented to increase cultivation surface and plant productivity, which have promoted the constant and excessive use of synthetic fertilizers, costly agricultural supplies, and to an extreme, contaminants both in soil and water, linked to human and animal health problems (Schulz and Glaser, 2012; Watanabe et al., 2015).

Facing the excessive use of synthetic nutritional supplies, sustainable and innocuous agriculture production alternatives for natural resources have been designed, among others, a better use of biofertilizers based on different types of beneficial microorganisms, for example, those formulated with rhizobacterial strains capable of promoting plant growth and development (Noh-Medina et al., 2014; HernándezMontiel et al., 2017; Naili et al., 2018); among the rhizobacterial communities, numerous species that stand out are in the genera: Azotobacter, Pseudomonas, Bacillus, Enterobacter, Rhizobium, Azospirillum, among others of agricultural importance (Kamou et al., 2015; Espinosa et al., 2017; Pérez-Velasco et al., 2019).

Rhizobacteria as bio-fertilizer agents are capable of directly and indirectly stimulating plant growth, development and productivity by different metabolic routes, such as mineral phosphorus solubilization, biological fixation of the nitrogen found in the atmosphere (Zaidi et al., 2015; Coy et al., 2019) and plant hormone production, such as auxins and gibberellins and cytokinins (Hernández-Montiel et al., 2017; Puente et al., 2018). Because of the effects that rhizobacteria have in plants, they are considered natural elicitor microorganisms with the ability of improving crop growth and productivity; thus, they are 
vegetales como auxinas, giberelinas y citosinas (Hernández-Montiel et al., 2017; Puente et al., 2018). Debido a los efectos que presentan las rizobacterias en las plantas, estos son considerados microorganismos elicitores naturales con la habilidad de mejorar crecimiento y productividad de los cultivos, resultando ser una alternativa biotecnológica como biofertilizante factible de bajo costo y fácil aplicación, aprovechable en la producción sustentable y no contaminante de cultivos agrícolas establecidos en campo o invernadero, favoreciendo la reducción de fertilizantes sintéticos que dañan al ambiente (Yang et al., 2009; Sunar et al., 2015; Dar et al., 2018).

Estudios sobre la aplicación de rizobacterias y fertilizantes sintéticos reportan aumentos en el crecimiento de las plantas, como resultado de una mayor capacidad de absorción y asimilación de nutrimentos promovida por el aumento poblacional y acción metabólica rizobacteriana (Dinesh et al., 2013; Díaz et al., 2018; Tahir et al., 2018). Al respecto ChiquitoContreras et al. (2017), señalan que la aplicación de rizobacterias de la especie Pseudomonas putida más fertilización sintética reducida al $75 \%$ de macro y micronutrimentos incrementó significativamente el rendimiento de fruto y crecimiento vegetativo de chile habanero en invernadero. Por su parte Naseri y Mirzaei (2010) en un estudio similar indican que la aplicación de rizobacterias del género Azotobacter y Azospirillum con fertilización sintética reducida al $50 \%$ de nitrógeno inorgánico en condiciones de campo incrementó significativamente el crecimiento de plantas de cártamo. En el estudio realizado en campo por Yousefi y Barzegar (2014), reportan rendimientos similares en plantas de trigo tratadas con fertilizante fosforado al $100 \%$ y plantas inoculadas con Azotobacter chrocooccum y Pseudomonas fluorescens con aplicación del 50\% del mismo fertilizante sintético. Aun cuando es consistente el efecto positivo de la combinación de rizobacterias con dosis reducidas de fertilizantes sintéticos en las plantas, es indispensable conocer y determinar la mejor combinación que facilite el proceso sinérgico entre los agentes biológicos e insumos nutricionales sintéticos, que coadyuve en la obtención de mayor crecimiento y productividad de plantas de importancia económica (Hernández-Montiel et al., 2017; Tripti et al., 2017; Cordero et al., 2018). De acuerdo con lo antes descrito, el objetivo del presente estudio fue determinar el efecto de la inoculación de tres cepas rizobacterianas de Pseudomonas putida a biotechnological alternative as feasible biofertilizers with low cost and easy application, which can be used in sustainable and non-contaminant production of agricultural crops established in field or greenhouse, favoring the reduction of synthetic fertilizers that harm the environment (Yang et al., 2009; Sunar et al., 2015; Dar et al., 2018).

Studies on rhizobacteria and synthetic fertilizers have reported plant increase as a result of greater nutrient absorbance and assimilation capacity promoted by population increase and rhizobacterial metabolic action (Dinesh et al., 2013; Díaz et al., 2018; Tahir et al., 2018). In that respect Chiquito-Contreras et al. (2017) pointed out that the application of rhizobacteria of the species Pseudomonas putida with synthetic fertilization reduced at $75 \%$ of macro and micronutrients increased fruit yield and plant growth of bell pepper in greenhouse. On the other hand, Naseri and Mirzaei (2010) indicated in a similar study that the application of rhizobacteria of the genus Azotobacter and Azospirillum with synthetic fertilization reduced at $50 \%$ of inorganic $\mathrm{N}$ in field conditions increased safflower plant growth. In a study performed in field, Yousefi and Barzegar (2014) reported similar yields in wheat plants treated with phosphorus fertilizer at $100 \%$ and plants inoculated with Azotobacter chrocooccum and Pseudomonas fluorescens with the application of $50 \%$ of the same synthetic fertilizer. Even though the positive effect of combining rhizobacteria with reduced doses of synthetic fertilizers in plants is consistent, it is essential to know and determine the best combination that facilitates the synergic process between the biological agents and synthetic nutritional supplies that contribute to obtain the greatest growth and productivity of economically important plants (Hernández-Montiel et al., 2017; Tripti et al., 2017; Cordero et al., 2018). Therefore, the objective of this study was to determine the effects of inoculating three rhizobacterial strains of Pseudomonas putida and applying two synthetic fertilization concentrations on the morphological parameters and fruit yield in bell pepper plants in greenhouse conditions.

\section{MATERIALS AND METHODS}

\section{Study Area}

This research study was implemented in a greenhouse type tunnel of $160 \mathrm{~m}^{2}$ and $3 \mathrm{~m}$ in height in the 
y aplicación de dos concentraciones de fertilización sintética sobre parámetros morfológicos y rendimiento de fruto en plantas de pimiento morrón en condiciones de invernadero.

\section{MATERIALES Y MÉTODOS}

\section{Área de Estudio}

La investigación se implementó en un invernadero tipo túnel de $160 \mathrm{~m}^{2}$ y $3 \mathrm{~m}$ de altura en la parte central con ventilación lateral, localizado en la Facultad de Ciencias Agrícolas-Xalapa de la Universidad Veracruzana, a una altura de $1450 \mathrm{msnm}$, cuyas coordenadas geográficas son: $19^{\circ} 30^{\prime} \mathrm{N}$ y $96^{\circ} 55^{\prime} \mathrm{O}$, en la ciudad de Xalapa, Veracruz, México.

\section{Obtención y Crecimiento de Rizobacterias}

Se utilizaron tres cepas de Pseudomonas putida clasificadas como FA-8, FA-56 y FA-60, proporcionadas por el Laboratorio de Química Agrícola perteneciente a la Facultad de Ciencias Agrícolas-Xalapa. Las rizobacterias fueron cultivadas individualmente en medio líquido B-King (compuesto por: peptona

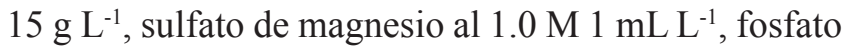
de potasio dibásico $1.5 \mathrm{~g} \mathrm{~L}^{-1}$ y glicerol $10 \mathrm{~mL} \mathrm{~L}^{-1}$ ), posteriormente se colocaron en una incubadora (Binder ${ }^{\mathrm{TM}} \mathrm{BF} 400$, Tuttlingen, Alemania) durante $48 \mathrm{~h} \mathrm{a}$ $26^{\circ} \mathrm{C}$ con agitación orbital a $180 \mathrm{rpm}$. La concentración de cada rizobacteria fue ajustada a $1 \times 10^{9}$ células $\mathrm{mL}^{-1}$ (mediante disolución con solución estéril de $\mathrm{NaCl}$ del $0.85 \% \mathrm{p} / \mathrm{v}$ ) utilizando un espectrofotómetro digital (Thermo Spectronic Genesys 20, corporación Fisher Scientific, Waltham, Massachusetts, USA), calibrado a una longitud de onda de $660 \mathrm{~nm}$ hasta obtener una absorbancia de 1.0 en la concentración de cada cultivo bacteriano.

\section{Producción de Plántulas de Pimiento (Capsicum annuum L.)}

Para la obtención de plántulas de pimiento morrón se utilizaron semillas de la variedad 'California Wonder' de la compañía Hortaflor-Rancho Los Molinos $^{\circledR}$ (Tepoztlán, Morelos, México), cultivar caracterizado por presentar frutos cuadrados, gruesos $\mathrm{y}$ dulces, con crecimiento vegetativo determinado y central part with lateral ventilation, in the experimental field of the Facultad de Ciencias Agrícolas-Xalapa at Universidad Veracruzana (UV) located at $1450 \mathrm{~m}$ above the sea level, $19^{\circ} 30^{\prime} \mathrm{N}$ and $96^{\circ} 55^{\prime} \mathrm{W}$ in the city of Xalapa, Veracruz, México.

\section{Obtaining Rhizobacteria and Growth}

Three Pseudomonas putida strains, classified as FA-8, FA-56, and FA-60, provided by the Chemical Agriculture Laboratory from the Facultad de Ciencias Agrícolas-Xalapa were used. The rhizobacteria were cultivated individually in King's B medium (composed of: peptone $15 \mathrm{~g} \mathrm{~L}^{-1}$, magnesium sulfate at $1.0 \mathrm{M}$ $1 \mathrm{~mL} \mathrm{~L}^{-1}$, dipotassium phosphate $1.5 \mathrm{~g} \mathrm{~L}^{-1}$ and glycerol $10 \mathrm{~mL} \mathrm{~L}^{-1}$ ), subsequently placed in an incubator (Binder ${ }^{\mathrm{TM}}$ model BF 400 , Tuttlingen, DE) at $26^{\circ} \mathrm{C}$ with orbital agitation at $180 \mathrm{rpm}$ for $48 \mathrm{~h}$. The concentration of each rhizobacteria was adjusted to $1 \times 10^{9}$ cells $\mathrm{mL}^{-1}$ (by dissolution with sterile solution of $\mathrm{NaCl}$ at $0.85 \%$ $\mathrm{p} / \mathrm{v}$ ) utilizing a digital spectrophotometer (Thermo Spectronic Genesys 20, Fisher Scientific, Inc., Waltham, MA, USA) calibrated at a wavelength of $660 \mathrm{~nm}$ until an absorbance of 1.0 was obtained in the concentration of each bacterial culture.

\section{Bell Pepper (Capsicum annuum L.) Seedling Production}

To obtain bell pepper plants, the seeds used were of the variety 'California Wonder' cultivar of the company Hortaflor-Rancho Los Molinos ${ }^{\circledR}$ (Tepoztlán, Morelos, México), characterized by having square, thick and sweet fruit with determined plant growth and semiprecocious cultivation cycle. For seed germination, a $2.5 \times 2.5 \times 6 \mathrm{~cm}$ rigid polystyrene germinator 200-well tray was used, previously disinfected with sodium hypochlorite at 5\%; the germinator cavities were filled with substrate based on pumice, sand and vermi-compost in a ratio of 2:1:2(v/v), disinfected and sanitized with Anibac $580^{\circledR}$ liquid solution (Promotora Técnica Industrial, S.A. de C.V. Jiutepec, Morelos, México, active ingredient: double-chain quaternary ammonium salts at $3.7 \%$ and first generation quaternary ammonium at $8.6 \%$ ) in a dose of $10 \mathrm{~mL} \mathrm{~L}^{-1}$. One seed per tray well was placed at depth of $1 \mathrm{~cm}$ and subsequently left at greenhouse temperature conditions of $25 \pm 3{ }^{\circ} \mathrm{C}$ and relative humidity of $55 \pm 5 \%$ for 40 days; irrigation 
ciclo de cultivo semi-precoz. Para la germinación de las semillas se utilizó una bandeja germinadora de 200 cavidades de poliestireno rígido con dimensiones de $2.5 \times 2.5 \times 6 \mathrm{~cm}$, la cual previamente se desinfectó con hipoclorito de sodio al 5\%, las cavidades de la bandeja fueron llenadas con el sustrato a base de tepetzil, arena y lombricomposta en relación 2:1:2 $(\mathrm{v} / \mathrm{v})$, desinfectada y sanitizada con una solución líquida de Anibac 580 ${ }^{\circledR}$ (Promotora Técnica Industrial, S.A. de C.V. Jiutepec, Morelos, México; ingrediente activo: sales cuaternarias de amonio de doble cadena al $3.7 \%$ y cuaternario de amonio de primera generación al $8.6 \%$ ) a una dosis de $10 \mathrm{~mL} \mathrm{~L}^{-1}$. En cada cavidad de la bandeja a una profundidad de $1 \mathrm{~cm}$ fue colocada una semilla, posteriormente la bandeja germinadora permaneció por un periodo de 40 días en condiciones de invernadero a temperatura de $25 \pm 3{ }^{\circ} \mathrm{C}$ y humedad relativa de $55 \pm 5 \%$, se aplicaron riegos con agua corriente diariamente hasta la obtención de plantas con altura de $18 \mathrm{~cm}$ en promedio al momento del trasplante.

\section{Trasplante y Biofertilización de Plantas de Pimiento con $P$. putida}

Al momento del trasplante la raíz de cada plántula fue lavada con agua destilada, posteriormente se establecieron diez grupos con ocho plántulas dentro de vasos de precipitados de $250 \mathrm{~mL}$ de capacidad para su inoculación por inmersión de las raíces en $150 \mathrm{~mL}$ de suspensión bacteriana $\left(1 \times 10^{9}\right.$ células $\left.\mathrm{mL}^{-1}\right)$ durante 20 min para cada cepa rizobacteriana de forma individual y combinación de las tres cepas (tratamiento MIX). Al finalizar el tiempo de inmersión las plántulas se depositaron en bolsas de polietileno $(40 \times 40 \mathrm{~cm})$ con capacidad de $10 \mathrm{~kg}$, las cuales contenían $9 \mathrm{~kg}$ de tepetzil como sustrato inerte, previamente lavado con agua corriente y desinfectado mediante la aplicación de una solución líquida de Anibac $580^{\circledR}$ en concentración de $5 \mathrm{~mL} \mathrm{~L}^{-1}$. El diseño experimental implementado fue de bloques completamente al azar con diez tratamientos y ocho plantas como repetición, de los cuales dos grupos de plantas sin aplicación de suspensión bacteriana se les suministro solución nutritiva al 75 y $100 \%$ de concentración como tratamiento control. Establecido el experimento las plantas fueron fertilizadas diariamente con solución nutritiva, la cual se dosificó de acuerdo con las etapas de desarrollo vegetativo del cultivo, a los dos días después del trasplante (ddt) se aplicó with tap water was applied daily until a plant height of $18 \mathrm{~cm}$ in average was obtained at the moment of transplant.

\section{Transplant and Biofertilization of Bell Pepper Plants with Pseudomonas putida}

At the moment of transplanting, the root of each seedling was washed with distilled water; subsequently, 10 groups were established with eight seedlings in $250 \mathrm{~mL}$ beakers for inoculation by root immersion in $150 \mathrm{~mL}$ of bacterial suspension $\left(1 \times 10^{9}\right.$ cells $\left.\mathrm{mL}^{-1}\right)$ individually and combined with the three rhizobacterial strains (MIXED treatment) for $20 \mathrm{~min}$. At the end of immersion time, the seedlings were deposited in $10 \mathrm{~kg}$ polyethylene bags $(40 \times 40 \mathrm{~cm})$ containing $9 \mathrm{~kg}$ of pumice as inert substrate, previously washed with tap water, and disinfected by applying Anibac $580^{\circledR}$ liquid solution in a concentration of $5 \mathrm{~mL} \mathrm{~L}^{-1}$. The experiment was a randomized complete block design with 10 treatments and eight plants as replicate, of which two groups of plants without bacterial suspension application were provided a nutritive solution at 75 and $100 \%$ of concentration as control treatments. When the experiment was established, the plants were fertilized daily with the nutritive solution, dosed according to the plant development cultivation stage; two days after transplant (DAT), $0.3 \mathrm{~L}$ of nutritive solution were applied per plant; the volume was increased at $1 \mathrm{~L} \mathrm{day}^{-1}$ at $25 \mathrm{DAT}$ and $1.8 \mathrm{~L}_{\text {day }}{ }^{-1}$ from 70 DAT until the end of the experiment. The concentrations of the nutritive solution provided to the plants were 75 and $100 \%$ (Table 1), both solutions with the $\mathrm{pH}$ adjusted to 6.0. All the bell pepper plants remained in greenhouse for a period of 135 DAT; during the experimental stage, an average temperature of $25 \pm 2{ }^{\circ} \mathrm{C}$ and relative humidity of $55-60 \%$ were maintained. When the experimental stage concluded, the following quantifications were performed: stem diameter $(\mathrm{mm})$, height $(\mathrm{cm})$, radicle volume $\left(\mathrm{cm}^{3}\right)$, root length $(\mathrm{cm})$, fresh biomass $(\mathrm{g})$, dry biomass $(\mathrm{g})$, colony forming units (CFU) in roots, fresh fruit weight (g) and percentage of total soluble solids content in fruit juice (three fruit per plant) by the refractometry method (Refracto 30PX, Mettler Toledo, Columbus, $\mathrm{OH}, \mathrm{USA}$ ) expressed as ${ }^{\circ}$ Brix. 
$0.3 \mathrm{~L}$ de solución nutritiva por planta, el volumen se incrementó a $1 \mathrm{~L}_{\text {día }}{ }^{-1}$ a $\operatorname{los} 25$ ddt y $1.8 \mathrm{~L} \mathrm{día}^{-1}$ a partir de los $70 \mathrm{ddt}$ hasta finalizar el experimento. Las concentraciones de solución nutritiva suministrada a las plantas fueron del 75 y 100\% (Cuadro 1), ambas soluciones con $\mathrm{pH}$ ajustado en 6 . Todas las plantas de pimiento morrón permanecieron en invernadero por un periodo de 135 días después del trasplante, durante la fase experimental se mantuvo una temperatura promedio de $25 \pm 2{ }^{\circ} \mathrm{C}$ y humedad relativa del $55-60 \%$. Al concluir la fase experimental se efectuaron las siguientes cuantificaciones: diámetro de tallo $(\mathrm{mm})$, altura $(\mathrm{cm})$, volumen radical $\left(\mathrm{cm}^{3}\right)$, longitud de raíz $(\mathrm{cm})$, biomasa fresca $(\mathrm{g})$, biomasa seca $(\mathrm{g})$, unidades formadoras de colonias (UFC) en raíces, peso fresco de frutos (g) y contenido porcentual de sólidos solubles totales en jugo de fruto (tres frutos por planta) por el método refractométrico (Refracto 30PX, Mettler Toledo, Columbus, Ohio, USA) expresado como ${ }^{\circ}$ Brix.

\section{Cuantificación de Población Rizobacteriana en Raíces}

La determinación de poblaciones rizobacterianas (UFC) presentes en las raíces de las plantas de pimiento morrón se realizó al finalizar la fase experimental, para tal propósito se efectuó la colecta de una muestra compuesta por $3 \mathrm{~g}$ de raíces frescas procedentes de plantas biofertilizadas con las cepas rizobacterianas y sin biofertilizar (control), las muestras de raíces de los diferentes tratamientos evaluados fueron colocadas

\section{Quantification of Rhizobacterial Population in Roots}

The colony-forming unit (CFU) of the rhizobacteria in bell pepper plant roots was estimated at the end of the experimental stage. For such purpose, a sample composed of $3 \mathrm{~g}$ of fresh roots from bio-fertilized plants with rhizobacterial strains and without biofertilizer (control group) were collected; the root samples of the different treatments assessed were placed individually in Petri boxes, which contained a sterilized physiological solution of $\mathrm{NaCl}(0.85 \% \mathrm{p} / \mathrm{v})$. Subsequently, following Holguin and Bashan (1996) methodology, the roots were macerated with a sterilized glass rod; from the mixture obtained, $1 \mathrm{~mL}$ was collected and deposited inside a test tube; then, $9 \mathrm{~mL}$ of sterile physiological solution of $\mathrm{NaCl}(0.85 \% \mathrm{p} / \mathrm{v})$ were added to reach a final volume of $10 \mathrm{~mL}$; from the final volume obtained, serial dilutions were performed to obtain CFU in triplicate for each treatment in Petri plates containing solid B-King culture medium; the Petri plates were incubated at a constant temperature of $26{ }^{\circ} \mathrm{C}$ for a period of $72 \mathrm{~h}$. The rhizobacterial population obtained in each treatment was expressed as CFU $\log 10^{7} \mathrm{~g}^{-1}$ of root.

\section{Statistical Data Analysis}

With the data obtained in the variables of study, the respective analysis of variance (ANOVA) and Tukey's $(P \leq 0.05)$ multiple comparison of means were

Cuadro 1. Cantidad de fertilizantes sintéticos utilizados en la elaboración de solución nutritiva suministrada a plantas de pimiento morrón para su crecimiento y producción.

Table 1. Quantity of synthetic fertilizers used in the production of nutritive solution provided to bell pepper plants for their growth and production.

\begin{tabular}{|c|c|c|c|}
\hline Fertilizante comercial / Commercial fertilizer & Fórmula / Formula & $\begin{array}{c}\text { Cantidad (Dosis al } 100 \% \text { ) / } \\
\text { Quantity (Dose at 100\%) }\end{array}$ & $\begin{array}{c}\text { Cantidad (Dosis al } 75 \% \text { ) / } \\
\text { Quantity (Dose at } 75 \% \text { ) }\end{array}$ \\
\hline & & & $--\mathrm{gL}^{-1} \ldots$ \\
\hline Nitrato de calcio / Calcium nitrate & $\mathrm{Ca}\left(\mathrm{NO}_{3}\right)_{2} \cdot 4 \mathrm{H}_{2} \mathrm{O}$ & 1.43 & 1.07 \\
\hline Nitrato de magnesio / Magnesium nitrate & $\mathrm{Mg}\left(\mathrm{NO}_{3}\right)_{2}$ & 0.90 & 0.67 \\
\hline Nitrato de potasio / Potassium nitrate & $\mathrm{KNO}_{3}$ & 0.35 & 0.26 \\
\hline $\begin{array}{l}\text { Fosfato monopotásico / Monopotassium } \\
\text { phosphate Monopotassium }\end{array}$ & $\mathrm{KH}_{2} \mathrm{PO}_{4}$ & 0.35 & 0.26 \\
\hline $\begin{array}{l}\text { Micronutrientes }\left(\operatorname{Tradecorp}^{\circledR} \mathrm{AZ}\right)^{\dagger} / \\
\text { Micronutrients }\left(\operatorname{Tradecorp}^{\circledR} \mathrm{AZ}\right)^{\dagger}\end{array}$ & $\mathrm{Fe}, \mathrm{Zn}, \mathrm{Mn}, \mathrm{B}, \mathrm{Cu}, \mathrm{Mo}$ & 0.04 & 0.03 \\
\hline
\end{tabular}

${ }_{\dagger}$ Trade Corporation International, S.A.U. (Madrid, España).

$\uparrow$ Trade Corporation International, S.A.U. (Madrid, ES). 
de forma individual en cajas Petri, las cuales contenían una solución fisiológica esterilizada de $\mathrm{NaCl}(0.85 \%$ $\mathrm{p} / \mathrm{v}$ ). Posteriormente, siguiendo la metodología de Holguin y Bashan (1996), las raíces se maceraron por medio de una varilla de vidrio esterilizada, de la mezcla obtenida se procedió a colectar $1 \mathrm{~mL}$ el cual se depositó dentro de un tubo de ensayo, a continuación se agregaron $9 \mathrm{~mL}$ de solución fisiológica estéril de $\mathrm{NaCl}(0.85 \% \mathrm{p} / \mathrm{v})$, alcanzando un volumen final de $10 \mathrm{~mL}$, a partir del volumen final obtenido se procedió a efectuar diluciones seriadas para la obtención de UFC por triplicado para cada tratamiento en placas de Petri conteniendo medio de cultivo B-King sólido, las placas de Petrí fueron incubadas por un periodo de $72 \mathrm{~h}$ a temperatura constante de $26{ }^{\circ} \mathrm{C}$. La población rizobacteriana obtenida en cada tratamiento se expresó como UFC $\log 10^{7} \mathrm{~g}^{-1}$ de raíz.

\section{Análisis Estadístico de Datos}

Con los datos obtenidos en las variables de estudio se realizó su respectivo análisis de varianza y comparación múltiple de medias de acuerdo con la prueba Tukey $(P \leq 0.05)$, mediante el paquete estadístico Statistica $^{\circledR}$ V. 10.0 para Windows (StatSoft).

\section{RESULTADOS Y DISCUSIÓN}

De acuerdo con los resultados obtenidos, el análisis estadístico muestra diferencias significativas $(P \leq 0.05)$ para las variables agronómicas de crecimiento $\mathrm{y}$ productividad de las plantas de pimiento morrón biofertilizadas de forma individual y combinada con las cepas rizobacterianas de $P$. putida más la aplicación de dos concentraciones de fertilización sintética (Cuadro 2). Las plantas inoculadas con la combinación de las cepas rizobacterianas FA-8, FA-56 y FA-60 (tratamiento MIX) más dosis de fertilización al $100 \%$ incrementaron la altura y biomasa fresca respecto al control (fertilización sintética al 100\%) en un $28.54 \%$ y $19.29 \%$ respectivamente, comparando con los resultados obtenidos para las mismas variables de altura y biomasa fresca en plantas con nutrición sintética en dosis del $75 \%$ e inoculadas con la cepa FA-56 y MIX se obtuvieron incrementos del 25.03 y $18.80 \%$ respectivamente en comparación con las plantas fertilizadas al 100\% (control), tales valores son destacables considerando que se utilizó $25 \%$ menos fertilizante sintético en la nutrición de las performed with the statistical package Statistica ${ }^{\circledR}$ v. 10.0 for Windows (StatSoft).

\section{RESULTS AND DISCUSSION}

According to the results obtained, the statistical analysis showed significant $(P \leq 0.05)$ differences for the agronomic variables of bio-fertilized bell pepper plant growth and productivity, individually and combined, with the rhizobacterial strains of $P$. putida and the application of two concentrations of synthetic fertilization (Table 2). The plants inoculated with the combination of rhizobacterial strains FA-8, FA-56, and FA-60 (MIX Treatment) with the fertilization dosage at $100 \%$ increased height and fresh biomass compared with the control (synthetic fertilization at 100\%) group in $28.54 \%$ and $19.29 \%$, respectively, and compared to the results obtained for the same height and fresh biomass variables in plants with synthetic nutrition in dosage at $75 \%$ inoculated with the strain FA-56 and MIX, obtaining an increase of 25.03 and $18.80 \%$, respectively; compared with the fertilized plants at $100 \%$, such values were outstanding considering that $25 \%$ less of the synthetic fertilizer was used in biofertilized plant nutrition. In the dry biomass and stem diameter variables, the plants with the FA-56 strain and synthetic fertilization at $75 \%$ showed an increase of 27.25 and $37.85 \%$, respectively, compared with the control plants with synthetic nutrition at $100 \%$.

For root length, radicle volume, and fruit yield the best result was obtained in bio-fertilized plants with the MIX treatment (combination of three rhizobacterial strains) with synthetic fertilization at $75 \%$, obtaining increases of $18.91,31.86$, and $25.78 \%$, respectively, compared with the control plants fertilized at $100 \%$. In the percentage of total sugar content ${ }^{\circ}$ Brix (total soluble solids) variable found in mature bell pepper, the results did not indicate the presence of significant $(P \leq 0.05)$ differences between the treatment of biofertilized plants with $P$. putida strains and synthetic nutrition in dosage of 75 and $100 \%$ (Table 2).

With respect to the increase in fruit growth and yield determined on bell pepper plants bio-fertilized with $P$. putida rhizobacteria and reduced synthetic fertilization at $75 \%$, the response observed was related with its metabolic capacity to produce regulating growth hormones, particularly of the auxin group, such as indole acetic acid (IAA) metabolic activity capable of inducing plant growth through cell division 
plantas biofertilizadas. En las variables biomasa seca y diámetro de tallo, las plantas con la cepa FA-56 y fertilización sintética al 75\% mostraron un aumento del 27.25 y $37.85 \%$ respectivamente, en comparación a las plantas control con nutrición sintética al 100\%.

Para longitud de raíz, volumen radical y rendimiento de fruto, el mejor resultado se obtuvo en las plantas biofertilizadas con el tratamiento MIX (combinación de las tres cepas rizobacterianas) con fertilización sintética al 75\%, obteniendo aumentos del 18.91, 31.86 y $25.78 \%$ respectivamente, con relación a las plantas control fertilizadas al $100 \%$. En la variable contenido porcentual de azucares totales ${ }^{\circ}$ Brix (sólidos solubles totales) presentes en jugo de fruto maduro de pimiento, los resultados no indican presencia de diferencias significativas $(P \leq 0.05)$ entre tratamientos de plantas biofertilizadas con las cepas de $P$. putida y nutrición sintética en dosis del 75 y $100 \%$ (Cuadro 2). and differentiation of expressed tissues in yield and biomass increase (Nadeem et al., 2016; Ghosh et al., 2018).

On the other hand, rhizobacteria have been described as having the ability to improve the mineral nutrition process in plants, facilitating its availability, and increasing nutriment absorption, such as N, P and chelating ions, as Fe (Kumar-Solanki et al., 2014; Singh et al., 2018). In that respect, several authors have pointed out the importance of using rhizobacterial strains of the genus Pseudomonas as biofertilizer agents because of their capacity to stimulate growth and/or productivity in plants of economic interest, such as tomato (Hernández-Montiel et al., 2017), habanero pepper (Chiquito-Contreras et al., 2017), bell pepper (Bacilio et al., 2016), potato (Arseneault et al., 2015), soybean (Rubina et al., 2018), wheat (Imperiali et al., 2017), maize (Di Salvo et al., 2018), among others.

Cuadro 2. Efecto de la inoculación de Pseudomonas putida y fertilización sintética en el crecimiento de plantas y rendimiento de fruto de pimiento morrón variedad 'California Wonder' en invernadero.

Table 2. Effect of Pseudomonas putida inoculation and synthetic fertilization on plant growth and fruit yield of bell pepper variety 'California Wonder' in greenhouse.

\begin{tabular}{|c|c|c|c|c|c|c|c|c|}
\hline Tratamientos / Treatment & $\begin{array}{l}\text { Altura / } \\
\text { Height }\end{array}$ & $\begin{array}{c}\text { Diámetro } \\
\text { de tallo / } \\
\text { Stem } \\
\text { diameter }\end{array}$ & $\begin{array}{c}\text { Longitud } \\
\text { radical / } \\
\text { Radicle } \\
\text { length }\end{array}$ & $\begin{array}{l}\text { Volumen } \\
\text { radical / } \\
\text { Radicle } \\
\text { volume }\end{array}$ & $\begin{array}{l}\text { Biomasa } \\
\text { fresca / } \\
\text { Fresh } \\
\text { biomass }\end{array}$ & $\begin{array}{c}\text { Biomasa } \\
\text { seca / } \\
\text { Dry } \\
\text { biomass }\end{array}$ & $\begin{array}{l}\text { Rendimiento / } \\
\text { Yield }\end{array}$ & $\mathrm{SST}^{\circ} \mathrm{Brix}$ \\
\hline & $\mathrm{cm}$ & $\mathrm{mm}$ & $\mathrm{cm}$ & $\mathrm{cm}^{3}$ & $\ldots \ldots$ & $--g_{-}$ & $\ldots \ldots$ & $\%$ \\
\hline \multicolumn{9}{|c|}{ Fertilización química $100 \%^{\dagger}$ / Synthetic fertilization $100 \%{ }^{\dagger}$} \\
\hline Cepa FA-8 & $106.00 \mathrm{ab}$ & $12.89 \mathrm{a}$ & $56.97 \mathrm{abc}$ & $79.00 \mathrm{ab}$ & $265.11 \mathrm{abc}$ & $82.30 \mathrm{ab}$ & $335.20 \mathrm{ab}$ & $8.5 \mathrm{a}$ \\
\hline Cepa FA-56 & $108.30 \mathrm{ab}$ & $13.47 \mathrm{a}$ & $57.29 \mathrm{abc}$ & $91.70 \mathrm{a}$ & $298.60 \mathrm{ab}$ & $87.80 \mathrm{ab}$ & $330.55 \mathrm{ab}$ & $8.8 \mathrm{a}$ \\
\hline Cepa FA-60 & $100.50 \mathrm{abc}$ & $12.62 \mathrm{a}$ & $57.04 \mathrm{abc}$ & $85.75 \mathrm{a}$ & $280.85 \mathrm{abc}$ & $79.50 \mathrm{abc}$ & $370.70 \mathrm{ab}$ & $8.5 \mathrm{a}$ \\
\hline MIX & $118.75 \mathrm{a}$ & $12.97 \mathrm{a}$ & $57.60 \mathrm{ab}$ & $89.50 \mathrm{a}$ & $311.85 \mathrm{a}$ & $94.40 \mathrm{a}$ & $400.30 \mathrm{a}$ & $9.0 \mathrm{a}$ \\
\hline Control & $92.38 \mathrm{bc}$ & $10.04 \mathrm{~b}$ & $50.08 \mathrm{bcd}$ & $70.15 b$ & $261.43 \mathrm{bc}$ & $75.05 \mathrm{bc}$ & $325.00 \mathrm{ab}$ & $8.5 \mathrm{a}$ \\
\hline \multicolumn{9}{|c|}{ Fertilización química 75\% / Synthetic fertilization $75 \%$} \\
\hline Cepa FA-8 & $96.88 \mathrm{abc}$ & $12.59 \mathrm{a}$ & $50.50 \mathrm{~cd}$ & $77.00 \mathrm{ab}$ & $267.94 \mathrm{abc}$ & $76.63 \mathrm{abc}$ & $316.63 \mathrm{~b}$ & $8.5 \mathrm{a}$ \\
\hline Cepa FA-56 & $115.50 \mathrm{a}$ & $13.84 \mathrm{a}$ & $56.60 \mathrm{abc}$ & $86.60 \mathrm{a}$ & $307.65 \mathrm{ab}$ & $95.50 \mathrm{a}$ & $353.75 \mathrm{ab}$ & $9.0 \mathrm{a}$ \\
\hline Cepa FA-60 & $110.70 \mathrm{ab}$ & $12.07 \mathrm{a}$ & $52.54 \mathrm{bcd}$ & 86.40 a & $282.95 \mathrm{abc}$ & $84.90 \mathrm{ab}$ & $347.80 \mathrm{ab}$ & $8.8 \mathrm{a}$ \\
\hline MIX & $114.00 \mathrm{ab}$ & $12.65 \mathrm{a}$ & $59.55 \mathrm{a}$ & $92.50 \mathrm{a}$ & $310.60 \mathrm{a}$ & $93.70 \mathrm{a}$ & $408.80 \mathrm{a}$ & $9.0 \mathrm{a}$ \\
\hline Control & $86.38 \mathrm{c}$ & $9.74 \mathrm{~b}$ & $48.60 \mathrm{~d}$ & $69.75 \mathrm{~b}$ & $240.54 \mathrm{c}$ & $62.74 \mathrm{c}$ & $300.55 \mathrm{~b}$ & $8.5 \mathrm{a}$ \\
\hline
\end{tabular}

$\overline{\mathrm{SST}}=$ sólidos solubles totales. Medias de la misma columna con letras distintas indican la presencia de diferencias significativas, según la prueba Tukey $(P \leq 0.05){ }^{\dagger}$ Solución nutritiva elaborada con: $\mathrm{KNO}_{3}, \mathrm{KH}_{2} \mathrm{PO}_{4}, \mathrm{Ca}\left(\mathrm{NO}_{3}\right)_{2} \cdot 4 \mathrm{H}_{2} \mathrm{O}, \mathrm{Mg}\left(\mathrm{NO}_{3}\right)_{2}$ y micronutrientes $(\mathrm{Zn}, \mathrm{Fe}, \mathrm{B}, \mathrm{Mn}, \mathrm{Mo} \mathrm{y} \mathrm{Cu}) .{ }^{\star} \mathrm{MIX}=\mathrm{Inoculación}$ simultánea con las tres cepas de Pseudomonas putida en plantas de pimiento morrón.

SST $=$ Total soluble solids. Means in the same column with different letters indicate significant differences, according to Tukey's $(P \leq 0.05)$ test. ${ }^{\dagger}$ Nutritive solution made with: $\mathrm{KNO}_{3}, \mathrm{KH}_{2} \mathrm{PO}_{4}, \mathrm{Ca}\left(\mathrm{NO}_{3}\right)_{2} \cdot 4 \mathrm{H}_{2} \mathrm{O}, \mathrm{Mg}\left(\mathrm{NO}_{3}\right)_{2}$ and micronutrients $(\mathrm{Zn}, \mathrm{Fe}, \mathrm{B}, \mathrm{Mn}, \mathrm{Mo}$ and $\mathrm{Cu}) .{ }^{*} \mathrm{MIX}=$ Simultaneous inoculation with the three Pseudomonas putida strains in bell pepper plants. 
En cuanto al aumento del crecimiento y rendimiento de fruto determinados en las plantas de pimiento biofertilizadas con las cepas rizobacterianas de la especie $P$. putida y dosis reducida de fertilización sintética al $75 \%$, la respuesta observada ésta relacionada con la capacidad metabólica de $P$. putida para producir hormonas reguladoras del crecimiento, particularmente del grupo de las auxinas como el ácido indolacético (AIA), actividad metabólica capaz de inducir el crecimiento vegetal, a través de la división celular y diferenciación de tejidos expresado en un incremento de biomasa y rendimiento (Nadeem et al., 2016; Ghosh et al., 2018).

Por otra parte, se ha descrito que las rizobacterias poseen la habilidad para mejorar el proceso de nutrición mineral de las plantas, al facilitar la disponibilidad y aumentar la absorción de nutrimentos como N, P y quelatización de iones como el Fe (Kumar-Solanki et al., 2014; Singh et al., 2018). Al respecto, diversos autores han señalado la importancia de utilizar cepas rizobacterianas del género Pseudomonas como agentes biofertilizantes, debido a su capacidad para estimular el crecimiento vegetal y/o productividad de plantas de interés económico como: tomate (Hernández-Montiel et al., 2017), chile habanero (Chiquito-Contreras et al., 2017), pimiento morrón (Bacilio et al., 2016), papa (Arseneault et al., 2015), soya (Rubina et al., 2018), trigo (Imperiali et al., 2017), maíz (Di Salvo et al., 2018), entre otros.

Díaz et al. (2015) indican que la aplicación en campo de agentes rizobacterianos de la especie Azospirillum brasilense en plantas de sorgo más fertilización sintética al 50\%, aumentó significativamente el número de granos por panoja, contenido de proteína y rendimiento total de grano, en comparación con las plantas de sorgo sin biofertilizar y con dosis de fertilización al 100\%.

Por su parte Carlier et al. (2008) en un estudio similar reportan que la biofertilización en campo de plantas de trigo con cepas de Pseudomonas sp. y dosis de fertilización sintética reducida al 50\% mostró un aumento significativo en el peso de semilla y número de espigas. Dubey et al. (2014) reportan que la inoculación de plantas de garbanzo con cepas rizobacterianas de Bacillus subtilis más fertilización sintética en dosis reducida al 50\%, mejoró significativamente el rendimiento de semilla, respecto a las plantas fertilizadas al $100 \%$ sin inocular. Chiquito-Contreras et al. (2017) al evaluar en plantas de chile habanero
Díaz et al. (2015) indicated that the application in field of rhizobacterial agents of the species Azospirillum brasilense in sorghum plants with synthetic fertilization at $50 \%$, increased the number of grains per panicle, protein content, and total grain yield compared with the sorghum plants without biofertilizer and with a fertilization dose at $100 \%$.

In a similar study, Carlier et al. (2008) reported that biofertilization of wheat plants in field with Pseudomonas sp. strains and synthetic fertilization dose reduced at $50 \%$ showed a relevant effect on seed weight and ears of wheat number with a significant increase in both. Dubey et al. (2014) reported that inoculation in chickpea plants with rhizobacterial strains of Bacillus subtilis and synthetic fertilization in reduced dosage at 50\%, improved seed yield compared with fertilized plants at $100 \%$ without inoculant. Chiquito-Contreras et al. (2017), while assessing the effect of different rhizobacterial $P$. putida strains and synthetic fertilization in a dose at $75 \%$ on habanero pepper plants, obtained a significant increase in fruit yield compared with plants with a dose at $100 \%$ of synthetic fertilization and without inoculation. These authors concluded that the application of a reduced dosage of synthetic fertilizers allowed a decrease in crop production costs, generating at the same time, a lower harmful impact toward the environment because of the continuous use of inorganic supplies. In this study, when bio-fertilized bell pepper plants were assessed with the three rhizobacterial $P$. putida strains (MIX treatment) and synthetic fertilization at $75 \%$, fruit yield showed a relevant increase of $25 \%$ compared with fertilized plants at $100 \%$.

With respect to nutritional fruit composition, particularly in total soluble solids content $\left({ }^{\circ} \mathrm{Brix}\right)$, some studies have pointed out that this organoleptic quality in fruits of bio-fertilized plants could be influenced by the rhizobacterial metabolic activity and potential to favor absorption and assimilation of essential nutrimental elements; additionally, the stimulation regulated by ethylene (Gamalero and Glick, 2015) a volatile organic compound that intervenes in enzyme production with a reduction function of sugars located on the fruit cell wall gives rise to simple monosaccharides that increase progressively during the fruit maturity stage (Ordookhani and Zare, 2011; Pérez-Velasco et al., 2019). 
el efecto de diferentes cepas rizobacterianas de P. putida con fertilización sintética en dosis del $75 \%$ en condiciones de invernadero, obtuvieron un incremento significativo en el rendimiento de fruto respecto a las plantas con dosis del 100\% de fertilización sintética y sin inocular, concluyendo que la aplicación de dosis reducidas de fertilizantes sintéticos permitirá una disminución en los costos de producción del cultivo, generando a su vez un menor impacto nocivo hacia el ambiente por el uso continuo de insumos inorgánicos. En el presente estudio al evaluar plantas de pimiento morrón biofertilizadas con las tres cepas rizobacterianas de P. putida (tratamiento MIX) y fertilización sintética al $75 \%$, mostró un incremento significativo en el rendimiento de fruto del $25 \%$, en comparación con las plantas control fertilizadas al $100 \%$.

En cuanto a la composición nutricional del fruto, en particular al contenido de solidos solubles totales ( ${ }^{\circ}$ Brix), algunos estudios señalan que esta cualidad organoléptica en frutos de plantas biofertilizadas, puede estar influenciada por la actividad metabólica y potencial de las rizobacterias para favorecer la absorción y asimilación de elementos nutrimentales esenciales, así como por la estimulación regulada por el etileno (Gamalero y Glick, 2015), compuesto orgánico volátil que interviene en la producción de enzimas con función reductora de los azúcares que se localizan en la pared celular del fruto, dando origen a monosacáridos simples que aumentan progresivamente durante la fase de maduración del fruto (Ordookhani y Zare, 2011; Pérez-Velasco et al., 2019).

Respecto a la tasa poblacional (UFC) de células bacterianas de $P$. putida cuantificadas en las muestras de raíces de las plantas de pimiento morrón, las cepas rizobacterianas más dosis de fertilización sintética al 75 y $100 \%$ mostraron diferencias significativas entre los tratamientos (Figura 1). Las plantas del tratamiento MIX biofertilizadas simultáneamente con las tres cepas de $P$. putida (FA-8, FA-56 y FA-60) más fertilización sintética al $75 \%$ mostraron la mayor tasa poblacional de células con 545 UFC $\left(10^{7} \mathrm{~g}^{-1}\right.$ de tejido fresco de raíces), por su parte, las plantas biofertilizadas con las cepas de forma individual y combinada más fertilización sintética al $100 \%$ mostraron poblaciones bajas de UFC.
As to the CFU of bacterial P. putida cells quantified in the bell pepper plant root samples, the rhizobacterial strains with the synthetic fertilization at 75 and $100 \%$, showed differences between treatments (Figure 1). The plants of the MIX treatment, bio-fertilized simultaneously with the three P. putida strains (FA-8, FA-56, and FA-60) and synthetic fertilization at 75\%, showed the greatest cell population rate with $545 \mathrm{CFU}$ $\left(10^{7} \mathrm{~g}^{-1}\right.$ of fresh root tissue) whereas the bio-fertilized plants with the individual and combined strains and synthetic fertilization at $100 \%$ showed the lowest CFU count.

Evidence has pointed out the negative effect of synthetic fertilizers on population rate and metabolic activity of the rhizobacteria inoculated in plants, as it occurs in different rhizobacterial species capable of performing biological fixation of atmospheric nitrogen, an essential nutritional element for optimum plant growth and metabolism (Pankievicz et al., 2015); generally, this type of microorganisms in the presence of inorganic nitrogen show a reduction on the metabolic biologic $\mathrm{N}$ fixation because the action of this type of rhizobacteria is particularly significant when this nutrimental element is scarce in the plant rhizosphere (Nadeem et al., 2016; Moreau et al., 2019).

Some studies have described that fluctuations in rhizobacterial population rate is conditioned to the type of the rhizobacterial inoculation method used on plants, as well as the quantity and quality of the organic compounds produced in root exudation, which highlights the presence of different hormone groups (such as, auxins, gibberellins and cytokinins), sugars, vitamins, amino acids, enzymes, organic acids, and phenols (Aung et al., 2016; Wu et al., 2018). Finally, both the amount and quality of the root exudate compounds were capable of stimulating rhizobacterial activity through competence of the metabolites present in the exudates; furthermore, the area where roots emerge, spaces between the unions of epidermal cells and growth zones, are the ideal points for proliferation of the microbial populations with greater adhesion, activity, and microbial attraction (Vacheron et al., 2013; Sasse et al., 2018). 


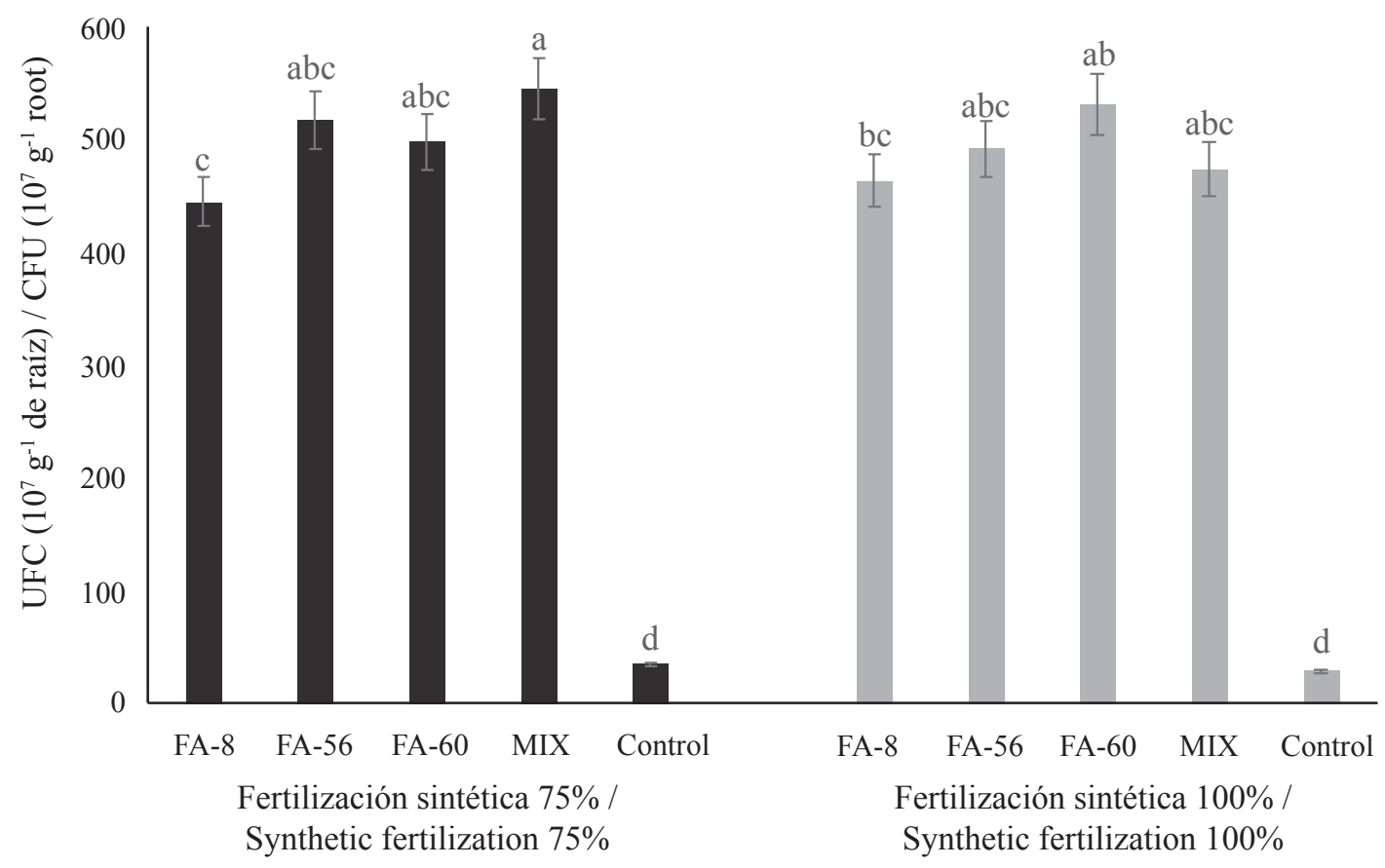

Figura 1. Unidades formadoras de colonias contabilizadas en raíces de plantas de pimiento morrón variedad 'California Wonder', biofertilizadas con cepas de Pseudomonas putida y plantas control con fertilización sintética, a los 135 días posteriores al transplante. Letras distintas presentes en las barras indican diferencias significativas, según la prueba de rango múltiple Tukey $(P \leq 0.05)$.

Figure 1. Colony forming unit count in bell pepper plant roots, variety 'California Wonder', biofertilized with Pseudomonas putida strains and control group of plants with synthetic fertilization at 135 days after transplant. Different letters in bars indicate significant differences according to Tukey's $(P \leq 0.05)$ multiple range test.

Hay evidencias que señalan el efecto negativo de los fertilizantes sintéticos sobre la tasa poblacional y actividad metabólica de las rizobacterias inoculadas en plantas, tal y como ocurre en diversas especies rizobacterianas capaces de realizar la fijación biológica del nitrógeno atmosférico, elemento nutricional esencial para el óptimo crecimiento y metabolismo de las plantas (Pankievicz et al., 2015), generalmente este tipo de microorganismos en presencia de nitrógeno inorgánico presentan una reducción en su habilidad metabólica para la fijación biológica de $\mathrm{N}$, debido a que la acción de este tipo de rizobacterias es particularmente significativa cuando este elemento nutrimental se encuentra escaso entorno a la rizósfera de las plantas (Nadeem et al., 2016; Moreau et al., 2019).

Algunos estudios han descrito que las fluctuaciones en la tasa poblacional de rizobacterias, está condicionada de acuerdo con el método de inoculación de las rizobacterias sobre las plantas, así como por la cantidad y calidad de los compuestos orgánicos

\section{CONCLUSIONS}

The determined response in bell pepper variety 'California Wonder' bio-fertilized with Pseudomonas putida strains, both individually and combined with synthetic fertilization dosage reduced at $75 \%$, showed the greatest increase in the different morphologic growth variables (root length, root volume, stem diameter, and dry biomass), bacterial population, and fruit production. The use of rhizobacteria may contribute to a decrease in synthetic fertilizer quantity supplied to plants up to $25 \%$, which allows a considerable reduction in production costs of bell pepper crop and contributes to soil fertility conservation besides minimizing environmental impact. Detailed studies in field conditions should be performed where the implementation of synthetic fertilization is contemplated in a reduced dosage to validate the capacity of the species $P$. putida rhizobacterial strains as bio-fertilizers capable of promoting plant growth 
producidos en la exudación de las raíces, sobresaliendo la presencia de diversos grupos hormonales (como las auxinas, giberelinas y citoquininas), azúcares, vitaminas, aminoácidos, enzimas, ácidos orgánicos y fenoles (Aung et al., 2016; Wu et al., 2018). Finalmente, tanto la cantidad como la calidad de los compuestos exudados generados por las raíces de las plantas son capaces de estimular la actividad de las rizobacterias a través de competencia por la diversidad de metabolitos presentes en los exudados, así como por el área que ocupan sobre las raíces, siendo los puntos idóneos para la proliferación de las poblaciones microbianas los espacios entre las uniones de las células epidérmicas y la zonas de crecimiento por donde emergen las raíces, zonas con mejor adhesión, mayor actividad y atracción microbiana (Vacheron et al., 2013; Sasse et al., 2018).

\section{CONCLUSIONES}

La respuesta determinada en las plantas de pimiento morrón variedad 'California Wonder', biofertilizadas con cepas de Pseudomonas putida de forma individual y combinada más fertilización sintética en dosis reducida al $75 \%$ mostró mayores incrementos en diferentes variables morfológicas de crecimiento (longitud de raíz, volumen de raíz, diámetro de tallo y biomasa seca), población bacteriana y producción de frutos. La utilización de rizobacterias puede contribuir a la disminución de la cantidad de fertilizantes sintéticos suministrados a las plantas hasta en un $25 \%$, permitiendo una reducción considerable en los costos de producción del cultivo de pimiento morrón, coadyuvar en la conservación de la fertilidad del suelo y minimizar el impacto ambiental. Es necesario realizar estudios detallados en condiciones de campo, en donde se contemple la implementación de fertilización sintética en dosis reducidas, para validar la capacidad de las cepas rizobacterianas de la especie $P$. putida como biofertilizantes capaces de promover el crecimiento vegetativo y rendimiento de fruto en plantas de pimiento morrón con un enfoque de producción agrícola sustentable y ecológicamente viable.

\section{AGRADECIMIENTOS}

Los autores del presente trabajo agradecen a la Facultad de Ciencias Agrícolas de la Universidad Veracruzana Campus Xalapa, el uso de instalaciones and fruit yield in bell pepper plants with a sustainable agriculture production approach and ecologically viable.

\section{ACKNOWLDEGMENTS}

The authors are grateful to the Facultad de Ciencias Agrícolas of Universidad Veracruzana Campus Xalapa, for using the facilities and technical support provided by the responsible staff of the Agricultural Chemistry Laboratory and greenhouse area; to D. Fischer for translation and editorial services.

-End of english version-

y soporte técnico proporcionado a través del personal responsable del Laboratorio de Química Agrícola y del área de invernaderos; a D. Fischer por los servicios de edición y traducción.

-Fin de la versión en español-

\section{REFERENCIAS / REFERENCES}

Arseneault, T., C. Goyer, and M. Filion. 2015. Pseudomonas fluorescens LBUM223 increases potato yield and reduces common scab symptoms in the field. Phytopathology 105: 1311-1317. doi: https://doi.org/10.1094/PHYTO-12-140358-R.

Aung, H. P., A. D. Mensah, Y. S. Aye, S. Djedidi, Y. Oikawa, T. Yokoyama, S. Suzuki, and S. D. Bellingrath-Kimura. 2016. Transfer of radiocesium from rhizosphere soil to four cruciferous vegetables in association with a Bacillus pumilus strain and root exudation. J. Environ. Radioact. 164: 209-219. doi: https://doi.org/10.1016/j.jenvrad.2016.07.006.

Bacilio, M., M. Moreno, and Y. Bashan. 2016. Mitigation of negative effects of progressive soil salinity gradients by application of humic acids and inoculation with Pseudomonas stutzeri in a salt-tolerant and a salt-susceptible pepper. Appl. Soil Ecol. 107: 394-404. doi: https://doi.org/10.1016/j. apsoil.2016.04.012.

Carlier, E., M. Rovera, A. Rossi Jaume, and S. B. Rosas. 2008. Improvement of growth, under field conditions, of wheat inoculated with Pseudomonas chlororaphis subsp. aurantiaca SR1. World J. Microbiol. Biotechnol. 24: 2653-2658. doi: https://doi.org/10.1007/s11274-008-9791-6. 
Coy, R. M., D. W. Held, and J. W. Kloepper. 2019. Rhizobacterial colonization of bermudagrass by Bacillus spp. in a Marvyn loamy sand soil. Appl. Soil Ecol. 141: 10-17. doi: https://doi. org/10.1016/j.apsoil.2019.04.018.

Chiquito-Contreras, R. G., B. Murillo-Amador, C. J. ChiquitoContreras, J. C. Márquez-Martínez, M. V. Córdoba-Matson, and L. G. Hernández-Montiel. 2017. Effect of Pseudomonas putida and inorganic fertilizer on growth and productivity of habanero pepper (Capsicum chinense Jacq.) in greenhouse. J. Plant Nutr. 40: 2595-2601. doi: https://doi.org/10.1080/01904 167.2017.1381119.

Cordero, I., L. Balaguer, A. Rincón, and J. J. Pueyo. 2018. Inoculation of tomato plants with selected PGPR represents a feasible alternative to chemical fertilization under salt stress. J. Plant Nutr. Soil Sci. 181: 694-703. doi: https://doi.org/10.1002/ jpln.201700480.

Dar, Z. M., A. Rouf, A. Masood, M. Asif, and M. A. Malik. 2018. Review on plant growth promoting rhizobacteria and its effect on plant growth. J. Pharmacogn. Phytochem. 7: 2802-2804.

Di salvo, L. P., G. C. Cellucci, M. E. Carlino, and I. E. García de Salamone. 2018. Plant growth-promoting rhizobacteria inoculation and nitrogen fertilization increase maize (Zea mays L.) grain yield and modified rhizosphere microbial communities. Appl. Soil Ecol. 126: 113-120. doi: https://doi. org/10.1016/j.apsoil.2018.02.010.

Díaz Franco, A., D. Gálvez López y F. E. Ortiz Cháirez. 2015. Bioinoculación y fertilización química reducida asociadas con el crecimiento de planta y productividad de sorgo. Rev. Int. Contam. Ambient. 31: 245-252.

Díaz Franco, A., F. E. Ortiz Cháirez, O. A. Grageda Cabrera y E. Fernández Cruz. 2018. Nutrición mineral y rendimiento de sorgo inoculado con cepas microbianas en dos agroambientes. Terra Latinoamericana 36: 229-238. doi: https://dx.doi. org/10.28940/terra.v36i3.295.

Dinesh, R., M. Anandaraj, A. Kumar, V. Srinivasan, Y. K. Bini, K. P. Subila, R. Aravind, and S. Hamza. 2013. Effects of plant growth-promoting rhizobacteria and NPK fertilizers on biochemical and microbial properties of soils under ginger (Zingiber officinale Rosc.) cultivation. Agric. Res. 2: 346-353. doi: https://doi.org/10.1007/s40003-013-0080-8.

Dubey, R. C., S. Khare, P. Kumar, and D. K. Maheshwari. 2014. Combined effect of chemical fertilisers and rhizospherecompetent Bacillus subtilis BSK17 on yield of Cicer arietinum. Arch. Phytopathol. Plant Protect. 47: 2305-2318. doi: https:// doi.org/10.1080/03235408.2013.876744.

Espinosa Palomeque, B., A. Moreno Reséndez, P. Cano Ríos, V. P. Álvarez Reyna, J. Sáenz Mata, H. Sánchez Galvány G. González Rodríguez. 2017. Inoculación de rizobacterias promotoras del crecimiento vegetal en tomate (Solanum lycopersicum L.) cv. afrodita en invernadero. Terra Latinoamericana 35: 169-178. doi: https://doi.org/10.28940/terra.v35i2.194.

Gamalero, E. and B. R. Glick. 2015. Bacterial modulation of plant ethylene levels. Plant Physiol. 169: 13-22. doi: https://doi. org/10.1104/pp.15.00284.

Ghosh, D., A. Gupta, and S. Mohapatra. 2018. Dynamics of endogenous hormone regulation in plants by phytohormone secreting rhizobacteria under water-stress. Symbiosis 77: 265278. doi: https://doi.org/10.1007/s13199-018-00589-w.
Hernández-Montiel, L. G., C. J. Chiquito-Contreras, B. MurilloAmador, L. Vidal-Hernández, E. E. Quiñones-Aguilar, and R. G. Chiquito-Contreras. 2017. Efficiency of two inoculation methods of Pseudomonas putida on growth and yield of tomato plants. J. Soil Sci. Plant Nutr. 17: 1003-1012. doi: http://dx.doi.org/10.4067/S0718-95162017000400012.

Holguin, G. and Y. Bashan. 1996. Nitrogen-fixation by Azospirillum brasilense $\mathrm{Cd}$ is promoted when co-cultured with a mangrove rhizosphere bacterium (Staphylococcus sp.). Soil Biol. Biochem. 28: 1651-1660. doi: https://doi.org/10.1016/S00380717(96)00251-9.

Imperiali, N., X. M. Chiriboga, K. Schlaeppi, M. Fesselet, D. Villacrés, G. Jaffuel, S. F. Bender, F. Dennert, R. Blanco-Pérez, M. G. A Van der Heijden, M. Maurhofer, F. Mascher, T. C. J. Turlings, C. Keel, and R. Campos-Herrera. 2017. Combined field inoculations of Pseudomonas bacteria, arbuscular mycorrhizal fungi, and entomopathogenic nematodes and their effects on wheat performance. Front. Plant Sci. 8: 1-17. doi: https://doi.org/10.3389/fpls.2017.01809.

Kamou, N. N., H. Karasali, G. Menexes, K. M. Kasiotis, M. C. Bon, E. N. Papadakis, G. D. Tzelepis, L. Lotos, and A. L. Lagopodi. 2015. Isolation screening and characterization of local beneficial rhizobacteria based upon their ability to suppress the growth of Fusarium oxysporum f. sp. radicis-lycopersici and tomato foot and root rot. Biocontrol Sci. Technol. 25: 928949. doi: https://doi.org/10.1080/09583157.2015.1020762.

Kumar-Solanki, M., R. Kumar-Singh, S. Srivastava, S. Kumar, P. Lal-Kashyap, A. K. Srivastava, and D. K. Arora. 2014. Isolation and characterization of siderophore producing antagonistic rhizobacteria against Rhizoctonia solani. J. Basic Microbiol. 54: 585-597. doi: https://doi.org/10.1002/jobm.201200564.

Moreau, D., R. D. Bardgett, D. Finlay, D. L. Jones, and L. Philippot. 2019. A plant perspective on nitrogen cycling in the rhizosphere. Funct. Ecol. 33: 540-552. doi: https://doi. org/10.1111/1365-2435.13303.

Nadeem, S. M., M. Ahmad, M. Naveed, M. Imran, Z. A. Zahir, and D. E. Crowley. 2016. Relationship between in vitro characterization and comparative efficacy of plant growthpromoting rhizobacteria for improving cucumber salt tolerance. Arch. Microbiol. 198: 379-387. doi: https://doi. org/10.1007/s00203-016-1197-5.

Naili, F., M. Neifar, D. Elhidri, H. Cherif, B. Bejaoui, M. Aroua, Z. Bejaoui, M. Abassi, K. Mguiz, H. Chouchane, H. I. Ouzari, and A. Cherif. 2018. Optimization of the effect of PGPR-based biofertilizer on wheat growth and yield. Biom. Biostat. Int. J. 7: 226-232. doi: https://doi.org/10.15406/bbij.2018.07.00213.

Naseri, R. and A. Mirzaei. 2010. Response of yield and yield components of safflower (Carthamus tinctorius L.) to seed inoculation with Azotobacter and azospirillum and different nitrogen levels under dry land condition. American-Eurasian J. Agric. Environ. Sci. 9: 445-449.

Noh-Medina, J., C. Yam-Chimal, L. Borges-Gómez, J. J. ZúñigaAguilar y G. Godoy-Hernández. 2014. Aislados bacterianos con potencial biofertilizante para plántulas de tomate. Terra Latinoamericana 32: 273- 281.

Ordookhani, K. and M. Zare. 2011. Effect of Pseudomonas, Azotobacter and Arbuscular Mycorrhizal Fungi (AMF) on lycopene, antioxidant activity and total soluble solid in tomato (Solanum lycopersicum L.) F1 Hybrid, Delta. Adv. Environ. Biol. 5: 1290-1294. 
Pankievicz, V. C., F. P. do Amaral, K. F. D. N. Santos, B. Agtuca, Y. M. J. Schueller, A. C. M. Arisi, M. B. R. Steffens, E. M. de Souza, F. O. Pedrosa, G. Stacey, and R. A. Ferrieri. 2015. Robust biological nitrogen fixation in a model grass-bacterial association. Plant J. 81: 907-919. doi: https://doi.org/10.1111/ tpj. 12777.

Pérez-Velasco, E. A., R. Mendoza-Villarreal, A. Sandoval-Rangel, M. Cabrera-de la Fuente, V. Robledo-Torres y L. A. ValdezAguilar. 2019. Evaluación del uso de endomicorrizas y Azospirillum sp. en la productividad y calidad nutracéutica de chile morrón (Capsicum annuum) en invernadero. ITEAInf. Tec. Econ. Agr. 115: 18-30. doi: https://doi.org/10.12706/ itea.2018.029.

Puente, M. L., J. L. Gualpa, G. A. Lopez, R. M. Molina, S. M. Carletti, and F. D. Cassán. 2018. The benefits of foliar inoculation with Azospirillum brasilense in soybean are explained by an auxin signaling model. Symbiosis 76: 41-49. doi: https://doi.org/10.1007/s13199-017-0536-x.

Rubina Noreen, H., F. Urooj, H. Farhat, H. A. Shafique, A. Rahman, and S. Ehteshamul-Haque. 2018. Impact of endonodule fluorescent Pseudomonas and Rhizobia on root rotting fungi and growth of soybean (Glycine max L. Merr.). Int. J. Biol. Res. 6: 27-33.

Sasse, J., E. Martinoia, and T. Northern. 2018. Feed your friends: Do plant exudates shape the root microbiome? Trends Plant Sci. 23: 25-41. doi: https://doi.org/10.1016/j.tplants.2017.09.003.

SIAP (Servicio de Información Agroalimentaria y Pesquera de México). 2017. Producción agrícola, resumen nacional por cultivo. http://www.siap.gob.mx/cierre-dela-produccionagricola-por-cultivo/. (Consulta: junio 05, 2019).

Singh, A. V., B. Prasad, and R. Goel. 2018. Plant growth promoting efficiency of phosphate solubilizing Chryseobacterium sp. PSR 10 with different doses of $\mathrm{N}$ and $\mathrm{P}$ fertilizers on lentil (Lens culinaris var. PL-5) growth and yield. Int. J. Curr. Microbiol. App. Sci. 7: 2280-2289. doi: https://doi. org/10.20546/ijcmas.2018.705.265.

Schulz, H. and B. Glaser. 2012. Effects of biochar compared to organic and inorganic fertilizers on soil quality and plant growth in a greenhouse experiment. J. Plant Nutr. Soil Sci. 175: 410-422. doi: https://doi.org/10.1002/jpln.201100143.
Sunar, K., P. Dey, U. Chkraborty, and B. Chakreborty. 2015. Biocontrol efficacy and plant growth promoting activity of Bacillus altitudinis isolated from Darjeeling hills, India. J. Basic Microbiol. 55: 91-104. doi: https://doi.org/10.1002/ jobm.201300227.

Tahir, M., U. Khalid, M. Ijaz, G. M. Shah, M. A. Naeem, M. Shahid, K. Mahmood, N. Ahmad, and F. Kareem. 2018. Combined application of bio-organic phosphate and phosphorus solubilizing bacteria (Bacillus strain MWT 14) improve the performance of bread wheat with low fertilizer input under an arid climate. Braz. J. Microbiol. 49: 15-24. doi: http://dx.doi. org/10.1016/j.bjm.2017.11.005.

Tripti, A. Kumar, Z. Usmani, V. Kumar, and Anshumali. 2017. Biochar and flyash inoculated with plant growth promoting rhizobacteria act as potential biofertilizer for luxuriant growth and yield of tomato plant. J. Environ. Manage. 190: 20-27. doi: https://doi.org/10.1016/j.jenvman.2016.11.060.

Vacheron, J., G. Desbrosses, M. L. Bouffaud, B. Touraine, Y. Moenne-Loccoz, D. Muller, L. Legendre, F. WisniewskiDye, and C. Prigent-Combaret. 2013. Plant growth-promoting rhizobacteria and root system functioning. Front. Plant Sci. 4: 1-19. doi: https://doi.org/10.3389/fpls.2013.00356.

Watanabe, M., Y. Ohta, S. Licang, N. Motoyama, and J. Kikuchi. 2015. Profiling contents of water-soluble metabolites and mineral nutrients to evaluate the effects of pesticides and organic and chemical fertilizers on tomato fruit quality. Food Chem. 169: 387-395. doi: https://doi.org/10.1016/j. foodchem.2014.07.155.

Wu, L., Y. Kobayashi, J. Wasaki, and H. Koyama. 2018. Organic acid excretion from roots: a plant mechanism for enhancing phosphorus acquisition, enhancing aluminum tolerance, and recruiting beneficial rhizobacteria. Soil Sci. Plant Nutr. 64: 697-704. doi: https://doi.org/10.1080/00380768.2018.1537093.

Yang, J., J. W. Kloepper, and C. M. Ryu. 2009. Rhizosphere bacteria help plants tolerate abiotic stress. Trends Plant Sci. 14: 1-4. doi: https://doi.org/10.1016/j.tplants.2008.10.004.

Yousefi, A.A. and A. R. Barzegar. 2014. Effect of Azotobacter and Pseudomonas bacteria inoculation on wheat yield under field condition. Int. J. Agric. Crop Sci. 7: 616-619.

Zaidi, A., E. Ahmad, M. S. Khan, S. Saif, and A. Rizvi. 2015. Role of plant growth promoting rhizobacteria in sustainable production of vegetables: Current perspective. Sci. Hortic. 193: 231-239. doi: https://doi.org/10.1016/j.scienta.2015.07.020. 